\title{
Citrus and Coffee Strains of Xylella fastidiosa Induce Pierce's Disease in Grapevine
}

\author{
W.-B Li and C.-H. Zhou, USDA-ARS, Beltsville, MD 20705; W. D. Pria, Jr., D. C. Teixeira, V. S. Miranda, \\ E. O. Pereira, and A. J. Ayres, Fundecitrus, Araraquara, 14807-040, SP, Brazil; C.-X. He and P. I. Costa, Institute \\ of Chemistry, UNESP, Araraquara, SP, Brazil; and J. S. Hartung, USDA-ARS, Beltsville, MD 20705
}

\begin{abstract}
Li, W.-B., Zhou, C.-H., Pria, W. D., Jr., Teixeira, D. C., Miranda, V. S., Pereira, E. O., Ayres, A. J., He, C.-X., Costa, P. I., and Hartung, J. S. 2002. Citrus and coffee strains of Xylella fastidiosa induce Pierce's disease in grapevine. Plant Dis. 86:1206-1210.

Xylella fastidiosa causes citrus variegated chlorosis (CVC) disease in Brazil and Pierce's disease of grapevines in the United States. Both of these diseases cause significant production problems in the respective industries. The recent establishment of the glassy-winged sharpshooter in California has radically increased the threat posed by Pierce's disease to California viticulture. Populations of this insect reach very high levels in citrus groves in California and move from the orchards into the vineyards, where they acquire inoculum and spread Pierce's disease in the vineyards. Here we show that strains of $X$. fastidios $a$ isolated from diseased citrus and coffee in Brazil can incite symptoms of Pierce's disease after mechanical inoculation into seven commercial Vitis vinifera varieties grown in Brazil and California. Thus, any future introduction of the CVC strains of $X$. fastidiosa into the United States would pose a threat to both the sweet orange and grapevine industries. Previous work has clearly shown that the strains of $X$. fastidiosa isolated from Pierce's disease- and CVC-affected plants are the most distantly related of all strains in the diverse taxon X. fastidiosa. The ability of citrus strains of X. fastidiosa to incite disease in grapevine is therefore surprising and creates an experimental system with which to dissect mechanisms used by $X$. fastidiosa in plant colonization and disease development using the full genome sequence data that has recently become available for both the citrus and grapevine strains of this pathogen.
\end{abstract}

Pierce's disease (PD) of grapevines ( $V i$ tis vinifera L.), caused by a strain of the bacterium Xylella fastidiosa (39), was first noted in California near Anaheim in 1884, and has been an important disease problem since that time in California. The disease prevents the cultivation of $V$. vinifera and French hybrid grapes in the southeastern United States, where the glassy-winged sharpshooter (GWSS), Homalodisca coagulata Say, is one of its insect vectors (4). The introduction (1) and establishment of the GWSS in California has accelerated the spread of the bacterium in vineyards $(26,30)$. The insect has been found in 15 counties in California and is established in 9 of these counties, threatening the $\$ 30$ billion California grape industry.

Citrus variegated chlorosis (CVC) is a destructive disease of citrus, first described from Macaubal in São Paulo State, Brazil, in 1987 (35), and later shown to be caused by a strain of $X$. fastidiosa $(5,14)$.

Corresponding author: J. S. Hartung

E-mail: hartungj@ba.ars.usda.gov

Accepted for publication 28 May 2002.

Publication no. D-2002-0828-01R

This article is in the public domain and not copyrightable. It may be freely reprinted with customary crediting of the source. The American Phytopathological Society, 2002.
The disease can be transmitted by contaminated budwood, sharpshooters, and natural root grafts (15). In the year 2000, $35 \%$ of the 200 million sweet orange trees in São Paulo State showed CVC symptoms (2), representing a direct loss of more than US\$100 million. CVC also has been found in almost all the other citrus production areas in Brazil, as well as in some regions of Argentina (3) and Costa Rica (W. Villa Lobos, personal communication).

Coffee leaf scorch (CLS), also known as Requeima do Café, is another economically important disease caused by a strain of X. fastidiosa. First described in São Paulo, Brazil, the disease is widespread and has apparently been present in Brazil as an unrecognized problem for a long time $(9,20)$, reducing coffee production in some plantations. Recently, CLS was also discovered in Costa Rica (34). Strains of $X$. fastidiosa isolated from citrus and coffee plants are closely related (32) and share the same sharpshooter insect vectors, and we have shown that the strains of $X$. fastidiosa from citrus could cause CLS disease in coffee plants (20).

Prior to the description of CVC disease, several strains of $X$. fastidiosa were isolated from sweet orange trees by Hopkins in Florida (19). Research has shown that these strains were probably PD strains resident in citrus, since PD was transmitted from these trees to grapevines using insect vectors (19) and PCR-based genomic characterization of these strains placed them within the PD group, but not the CVC group, of $X$. fastidiosa $(28,32)$. This indicates that the PD strains of $X$. fastidiosa could survive in, colonize, and be transmitted from citrus plants. Recent epidemiological data showed that proximity to citrus increased the incidence and severity of PD in grapevines in the Temecula Valley of California (25). This relationship occurs because in California the GWSS preferentially feeds and reproduces to high levels on citrus. Taken together, this suggests that commercial citrus plantations could serve as a reservoir of inoculum for PD strains of $X$. fastidiosa. However, despite numerous attempts, $X$. fastidiosa has not been isolated or detected in citrus that was experimentally inoculated with California grape strains of $X$. fastidiosa or from citrus trees growing adjacent to vineyards experiencing epidemic PD losses in Southern California (B. Hill, M. Blua, B. Kirkpatrick, and A.H. Purcell, unpublished data). It should also be pointed out that the PD strains of $X$. fastidiosa present in the United States apparently are not capable of inciting CVC, because citrus has been grown commercially in California and Florida for more than a century in the presence of PD-affected grapevines, and CVC has never been reported in the United States. However, it is not known whether the CVC strains of $X$. fastidiosa from South America, which clearly do colonize, multiply, and induce disease in citrus in South America, are capable of multiplying within and causing disease in grapevine. The objectives of this study were to determine if the citrus and coffee strains of $X$. fastidiosa could induce PD symptoms in grapevines after mechanical inoculation. If the CVC strains could incite $\mathrm{PD}$, the introduction of these strains into California would pose a tremendous threat to both the sweet orange and wine grape industries, given the high populations of GWSS found in many areas of California.

\section{MATERIALS AND METHODS}

Plant materials and management. Grape ( $V$. vinifera) seedlings were used in the experiments carried out at Fundecitrus, Araraquara, SP, Brazil. Seeds of grape varieties 'Pinot Noir' and 'Cabernet Sauvi- 
gnon' were kindly provided by Alexander Purcell, University of California, Berkeley. Seeds of grape varieties 'Beni Taka', 'Italia', 'Niagara', and 'Rubi' (all V. vinifera) were obtained from table fruit purchased at a market in Araraquara, SP, Brazil. The seeds were soaked in water with aeration for $24 \mathrm{~h}$, and then stored at $4^{\circ} \mathrm{C}$ for 30 days. The seeds were then sown in vermiculite and germinated after 2 weeks. Seedlings were transplanted 1 week later to pots (2 liters in volume) containing PlantMax (Eucatex, São Paulo, Brazil) based substrate consisting of the coffee formulation of PlantMax and composted bovine manure (50/50), supplemented with $300 \mathrm{~g}$ of Osmocote fertilizer (14:14:14) per 100 liters of substrate. Plants were watered daily, and Ridomil was applied as necessary as a soil drench in Brazil.

Rooted cuttings of grape variety 'Chardonnay' were used for the experiments carried out in ARS-USDA, Beltsville, MD. These plants were provided by Bruce Kirkpatrick, from the Foundation Plant Materials Service at the University of California, Davis. At both locations, all plants were maintained in screen-protected greenhouses throughout the experiments to preclude unintended transmission of the pathogen by insect vectors.

$X$. fastidiosa strains. In the experiment carried out at Fundecitrus, $X$. fastidiosa strains $9 a 5 c(21,37)$ and 2105 (20) from citrus and 3124 from coffee (20) were used to inoculate grapevines. These strains had previously been triply cloned and shown to be pathogenic in citrus or coffee plants. Bacteria were grown in liquid $\mathrm{PW}$ medium (8), at $30^{\circ} \mathrm{C}$ for 7 days prior to inoculation. All medium components were "tissueculture tested" grade (Sigma Chemical Co., St. Louis, MO). In the experiment carried out at Beltsville, three strains of $X$. fastidiosa were used. One was a PD strain (Temecula 042801) kindly provided by Bruce Kirkpatrick, University of California, Davis; the second strain was CVC strain 9a5c $(21,37)$, and the third was a fresh citrus isolate designated L001. This strain was isolated in April and triply cloned in May and June 2001 from CVCaffected 'Pera' sweet orange twigs collected from the Bebedouro Citrus Experiment Station, Bebedouro, SP, Brazil. Bacteria were grown in liquid $\mathrm{PW}$ medium at $30^{\circ} \mathrm{C}$ for 7 days prior to inoculation.

Plant inoculations. The inoculations in both experiments were done using 7-dayold $X$. fastidiosa cultures in liquid PW medium $\left(10^{8}\right.$ to $\left.10^{9} \mathrm{CFU} / \mathrm{ml}\right)$. Each plant was inoculated at 20 points on the stem using a 5-ml syringe with a $20 \mathrm{G}$ needle to simultaneously wound and deliver a droplet of inoculum (20). At Fundecitrus, each of the three strains of $X$. fastidiosa was injected into eight plants of each of the six grape cultivars (Table 1) on 15 March 2001. Eight control plants were mockinoculated with liquid PW medium only.
The plants in the experiments carried out at 2001, using five plants per strain of $X$. fastidiosa and another five plants inoculated with liquid PW medium as control. In the experiments carried out at Fundecitrus, the plants were 45 days old when inoculated and had four to six leaves. At Beltsville, the plants were cut $10 \mathrm{~cm}$ above the soil, and one new shoot was trained for each plant. The shoot was inoculated when it had four to six leaves and was allowed to grow after inoculation to as long as $2 \mathrm{~m}$. At both locations, plants were observed regularly for symptoms of PD (38).

Detection of $X$. fastidiosa. All test plants were assayed for $X$. fastidiosa by using double antibody sandwich enzymelinked immunosorbent assay (DASELISA) and polymerase chain reaction (PCR). DAS-ELISA was performed according to Chang et al. (5), with a polyclonal antibody raised against strain $9 \mathrm{a} 5 \mathrm{c}$ (Sanofi Diagnostic Pasteur, Marnes la Coquette, France). One gram of leaf petiole and midribs was ground in a Polytron blender in $2 \mathrm{ml}$ of phosphate-buffered sathrough cheesecloth, and an aliquot of 150 $\mu \mathrm{l}$ of the final filtrate was used for each well of the ELISA plate. For positive controls, cell suspensions of strains $9 \mathrm{a} 5 \mathrm{c}$, Beltsville were inoculated on 28 June line (PBS). The suspension was filtered

2105, and 3124 were adjusted to a KlettSummerson colorimeter reading of $50\left(10^{8}\right.$ to $\left.10^{9} \mathrm{CFU} / \mathrm{ml}\right)$. Aliquots of $150 \mu \mathrm{l}$ of the suspension were used per well of the ELISA plate. Colorimetric detection was done using alkaline phosphatase labeled antibody, and the plates were read at 405 $\mathrm{nm}$ after 30 min of incubation.

PCR assays were performed on xylem extracts obtained from petioles by using a syringe to displace the xylem contents with sterile deionized water (MilliQ, Bedford, MA) (10). The xylem extracts were diluted 1,000 -fold in deionized water. Diluted extracts $(200 \mu \mathrm{l})$ were transferred to PCR tubes and centrifuged at $12,000 \times g$ for 15 min. The supernatant was removed, and the pellet was dried at $65^{\circ} \mathrm{C}$ for $15 \mathrm{~min}$ and then suspended in $20 \mu \mathrm{l}$ of deionized water. PCR reagents and primers specific for $X$. fastidiosa, 272-1-int and 272-2-int (28), were added directly into the extracts and used for PCR amplification in a final reaction volume of $40 \mu \mathrm{l}$. The amplification program began with an incubation at $94^{\circ} \mathrm{C}$ for $4 \mathrm{~min}$ to lyse the bacteria, followed by 35 cycles of $94^{\circ} \mathrm{C}$ for $1 \mathrm{~min}, 64^{\circ} \mathrm{C}$ for 1 min, and $72^{\circ} \mathrm{C}$ for $1 \mathrm{~min}$, followed by a final extension cycle of $10 \mathrm{~min}$ at $72^{\circ} \mathrm{C}$. Following electrophoresis through agarose gels, PCR products were visualized by staining with ethidium bromide.

Table 1. Evaluation of grape plants inoculated with Xylella fastidiosa from citrus and coffee ${ }^{\mathrm{w}}$

\begin{tabular}{|c|c|c|c|c|c|}
\hline Grape variety & $\begin{array}{l}X . \text { fastidiosa } \\
\text { strain }\end{array}$ & $\begin{array}{c}\text { Number } \\
\text { inoculated }\end{array}$ & $\begin{array}{c}\text { ELISA }^{\mathbf{x}} \\
\text { positive (\%) }\end{array}$ & $\begin{array}{c}\text { PCR }^{\mathbf{y}} \\
\text { positive (\%) }\end{array}$ & $\begin{array}{c}\text { Symptomatic } \\
\text { plants }(\%)\end{array}$ \\
\hline \multirow[t]{3}{*}{ Beni Taka } & $9 \mathrm{a} 5 \mathrm{c}$ & 8 & 37.5 & 62.5 & 62.5 \\
\hline & 2105 & 8 & 25.0 & 50.0 & 50.0 \\
\hline & 3124 & 8 & 37.5 & 50.0 & 62.5 \\
\hline Subtotal/mean & 3 & 24 & 33.3 & 54.2 & 58.3 \\
\hline \multirow[t]{3}{*}{ Italia } & $9 \mathrm{a} 5 \mathrm{c}$ & 8 & 25.0 & 37.5 & 37.5 \\
\hline & 2105 & 8 & 12.5 & 12.5 & 0 \\
\hline & 3124 & 8 & 37.5 & 50.0 & 37.5 \\
\hline Subtotal/mean & 3 & 24 & 25.0 & 33.3 & 25.0 \\
\hline \multirow[t]{3}{*}{ Niagara } & $9 \mathrm{a} 5 \mathrm{c}$ & 8 & 62.5 & 75.0 & 87.5 \\
\hline & 2105 & 8 & 25.0 & 37.5 & 50.0 \\
\hline & 3124 & 8 & 50.0 & 62.5 & 62.5 \\
\hline Subtotal/mean & 3 & 24 & 45.8 & 58.3 & 66.7 \\
\hline \multirow[t]{3}{*}{ Rubi } & $9 \mathrm{a} 5 \mathrm{c}$ & 8 & 37.5 & 50.0 & 62.5 \\
\hline & 2105 & 8 & 25.0 & 25.0 & 37.5 \\
\hline & 3124 & 8 & 37.5 & 62.5 & 75.0 \\
\hline Subtotal/mean & 3 & 24 & 33.3 & 45.8 & 58.3 \\
\hline \multirow[t]{3}{*}{ Pinot Noir } & $9 \mathrm{a} 5 \mathrm{c}$ & 8 & 37.5 & 62.5 & 75.0 \\
\hline & 2105 & 8 & 25.0 & 50.0 & 50.0 \\
\hline & 3124 & 8 & 50.0 & 62.5 & 75.0 \\
\hline Subtotal/mean & 3 & 24 & 37.5 & 58.3 & 66.7 \\
\hline \multirow[t]{3}{*}{ Cabernet Sauvignon ${ }^{z}$} & $9 \mathrm{a} 5 \mathrm{c}$ & 16 & 31.3 & 56.3 & 68.8 \\
\hline & 2105 & 16 & 25.0 & 37.5 & 50.0 \\
\hline & 3124 & 16 & 37.5 & 62.5 & 81.3 \\
\hline Subtotal/mean & 3 & 48 & 31.3 & 52.1 & 66.7 \\
\hline \multirow[t]{3}{*}{ All cultivars } & $9 \mathrm{a} 5 \mathrm{c}$ & 56 & 37.5 & 57.1 & 64.3 \\
\hline & 2105 & 56 & 23.2 & 35.7 & 41.1 \\
\hline & 3124 & 56 & 41.1 & 58.9 & 67.9 \\
\hline Total & 3 & 168 & 33.9 & 50.6 & 57.7 \\
\hline
\end{tabular}

${ }^{w}$ All inoculated plants evaluated for the presence or absence of disease symptoms and tested for the presence of $X$. fastidiosa by both enzyme-linked immunosorbent assay (ELISA) and polymerase chain reaction (PCR).

${ }^{\mathrm{x}}$ Test was scored as positive for $X$. fastidiosa if the absorbance at $405 \mathrm{~nm}$ was three times that of the uninoculated control plants (5).

y Test was positive if a 600-bp product was produced by primer pair 272-1-int and 272-2-int (28).

${ }^{\mathrm{z}}$ Combined data of eight plants from each of two seed sources. 
Disease incidence and severity. At Fundecitrus, grapevines were scored for the presence or absence of typical symptoms of PD, and the data were recorded as percentage of plants showing symptoms. At Beltsville, a disease severity index (DSI) was calculated for 'Chardonnay' as follows, using data recorded at 10-day intervals following inoculation. The first 20 leaves of each plant were evaluated for the presence or absence of symptoms. The DSI was calculated based on the degree of symptom severity as measured by leaf scorch symptom: $0=$ healthy leaf, $1=$ leaf with less than $5.0 \%$ scorched area, $2=$ leaf with 5.1 to $10.0 \%$ scorched area, $3=$ leaf with 10.1 to $25.0 \%$ scorched area, $4=$ leaf with 25.1 to $50.0 \%$ scorched area, $5=$ leaf with more than $50 \%$ scorched area. The leaf scorch severity ratings were summed for each plant (20 leaves per plant) and divided by the number of leaves rated times the maximum possible rating $(20 \times 5$ $=100)$ to give the final DSI, with a range from 0 to 1 .

Analysis of variance was performed on the means of the disease severity index, and when significant, this was followed by a means comparison test (Tukey's) using a confidence level of $P=0.05$.

\section{RESULTS}

Development of Pierce's disease. At Fundecitrus, the 'Niagara' seedlings began to show typical PD leaf scorch symptoms 2 months postinoculation. The seedlings of the other five cultivars (Table 1) started to develop symptoms 3 months postinoculation. Strains 9a5c (Fig. 1) and 2105 from citrus and 3124 from coffee caused typical symptoms of PD in 'Niagara' seedlings, which included the presence of "green islands" on the stems caused by irregular lignification of the bark. With the exception of the seedlings of grape 'Italia' inoculated with CVC strain 2105, which did not show typical PD symptoms, the disease incidence (symptomatic/inoculated) ranged from 0.375 to 0.875 among seedlings of the six grape cultivars (Table 1).

At Beltsville, 'Chardonnay' plants developed symptoms 1 month postinoculation. Strains 9a5c (Fig. 2A) and L001 from citrus produced symptoms in 'Chardonnay' that were the same as those produced by the PD strain Temecula 042801 (Fig. 2B).

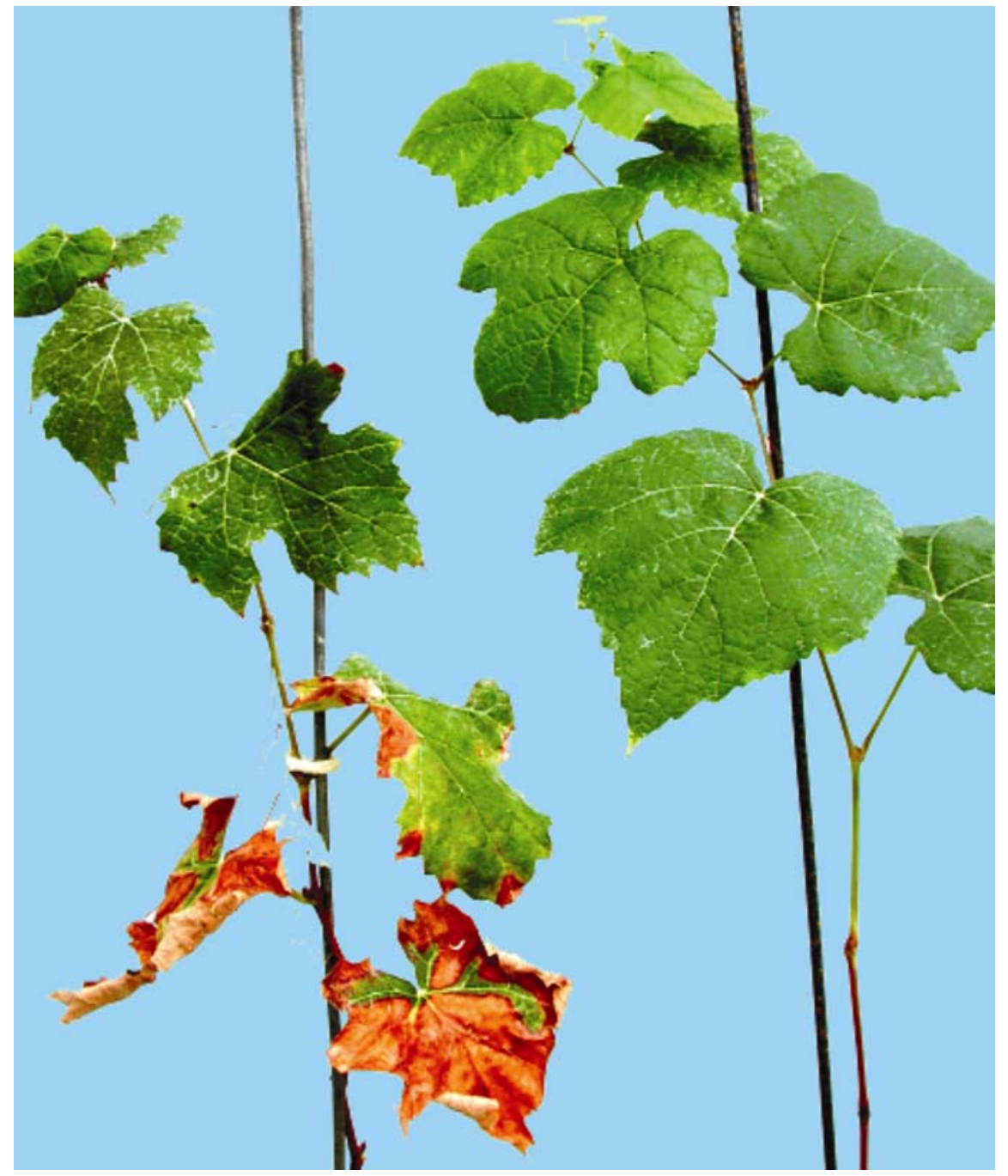

Fig. 1. Symptoms of Pierce's disease in 'Niagara' grapevine caused by the citrus strain 9a5c (37) of Xylella fastidiosa. The inoculated plant is on the left and the control plant is on the right.
However, the mean DSI was higher for the $\mathrm{PD}$ strain than for the CVC strains at 50 and 60 days postinoculation (Table 2). All 'Chardonnay' plants inoculated with PD or CVC strains produced typical PD symptoms in the experiment at Beltsville. No symptoms were observed on control plants mock-inoculated with pure PW medium at either Fundecitrus or Beltsville.

ELISA, PCR, and isolation of the pathogen. At Fundecitrus, 2 months postinoculation, most of the symptomatic plants gave positive ELISA reactions. However, $X$. fastidiosa was not detected by ELISA from more than one-third of the symptomatic plants of all six grape cultivars inoculated with different $X$. fastidiosa strains (Table 1). PCR tests for $X$. fastidiosa were negative from all parts of the plants of all six varieties unless the extracts were first washed in 1,000 volumes of water, indicating that grapevine extracts contained strong inhibitors of the PCR. Sodium ascorbate and polyvinylpyrrolidone (22) failed to prevent the inhibition in our experimental conditions. However, $X$. fastidiosa could be detected by PCR with the primer pair 272-1-int and 272-2-int (28) in extracts washed in 1,000 volumes of water from all of the ELISA-positive plants and some ELISA-negative ones. $X$. fastidiosa strains were easily isolated from the symptomatic plants during the period from 1 to 2 months postinoculation. Before or after this period, there were relatively more contaminants that interfered with the isolations. All of the inoculated strains were reisolated from the inoculated plants, and they did not differ morphologically (light microscope), serologically (ELISA), or by growth in PW medium compared with the original strain used as inoculum. The reisolated and original strains of $X$. fastidiosa produced a band of $600 \mathrm{bp}$ after PCR amplification with the specific primer pair 272-1-int and 272-2-int. No control plants gave positive ELISA or PCR reactions, and $X$. fastidiosa was never isolated from any control plants.

Susceptibility of grape cultivars to $X$. fastidiosa. Among the six grape cultivars inoculated in experiments at Fundecitrus, 'Niagara', 'Pinot Noir', and 'Cabernet Sauvignon' were the most susceptible to $X$. fastidiosa (Table 1). 'Niagara' had the highest rate of positive ELISA reactions among the three cultivars. 'Italia' was the least susceptible variety, and 'Beni Taka' was moderately susceptible to $X$. fastidiosa. At Beltsville, $100 \%$ of 'Chardonnay' plants inoculated either with PD strain Temecula 042801 or CVC strains from citrus plants developed typical symptoms of PD, consistent with the fact that 'Chardonnay' is very susceptible to PD (38). However, it is difficult to directly compare the susceptibility of 'Chardonnay' with that of the six grape cultivars used in the experiments in Brazil, because the greenhouse conditions at the two locations, al- 
though similar during the summer seasons when these experiments were conducted, were not exactly the same. PD strains of $X$. fastidiosa could not be included in the experiment in Brazil for phytosanitary reasons.

Relative pathogenicity $X$. fastidiosa strains from citrus and coffee. There were no consistent differences in the response of grapevines to strain $9 \mathrm{a} 5 \mathrm{c}$ from citrus and strain 3124 from coffee. Both produced typical symptoms of Pierce's disease (Table 1), and the two strains induced the same disease symptoms after mechanical inoculation of grape cultivars 'Benitaka', 'Italia', and 'Pinot Noir'. When inoculated on 'Niagara', strain 9a5c induced more diseased plants than did strain 3124; however, strain 3124 induced more diseased plants than strain 9a5c when inoculated on grape 'Rubi' and 'Cabernet Sauvignon'. The other CVC $X$. fastidiosa, strain 2105 from citrus, induced significantly fewer ELISA-positive, PCR-positive, and symptomatic plants, in all six inoculated grape cultivars, than did the other CVC and CLS strains. No typical symptoms of PD were observed from the inoculated plants of grape 'Italia' with the strain 2105. Taken together, this suggests that there may be variable interactions between these $X$. fastidiosa strains and specific $V$. vinifera varieties.

Disease severity on 'Chardonnay' grapevine. There was no significant difference in disease severity among the different $X$. fastidiosa strains 40 days postinoculation in 'Chardonnay' (Table 2). Fifty and sixty days postinoculation, disease severity was significantly higher for strain Temecula 042801 than for strains $9 \mathrm{a} 5 \mathrm{c}$ or L001. These results demonstrate that Temecula 042801 from grapevine was more pathogenic on grapevine than CVC strains $9 \mathrm{a} 5 \mathrm{c}$ and L001. There was no significant difference in the disease severity index of strains 9a5c and L001, indicating that there was no significant difference between the pathogenicity of the citrus strains 9a5c and L001 when inoculated into 'Chardonnay' grapevine.

\section{DISCUSSION}

$X$. fastidiosa has an exceptionally broad host range, with strains of the bacterium causing important diseases on a very wide range of shade and fruit trees (17,29). In some cases, individual strains are able to infect and incite disease in different hosts $(20,23,40)$, but in other cases cross infectivity experiments have given negative results (36). The bacterium is also able to infect and colonize a wide range of alternate hosts without causing disease $(11,18,33)$. The recent introduction and establishment of the glassy-winged sharpshooter into California has dramatically increased the threat that PD poses to the California grape and wine industries because it is a much more abundant vector for the pathogen than are the other leafhopper species native to California. Cali- fornia also has a significant sweet orange industry that is threatened by the potential introduction of strains of $X$. fastidios $a$ that cause CVC disease in Brazil.

Our results show that strains of $X$. fastidiosa that cause both CVC disease and CLS disease in South America also are capable of infecting, colonizing, and producing symptoms of PD in commercial grape cultivars ( $V$. vinifera). While $\mathrm{PD}$ strain Temecula 042801 killed one of the five 'Chardonnay' plants inoculated, neither of the citrus strains caused symptoms that progressed until the plants died. However, this experiment was abruptly terminated 88 days after inoculation, when a tornado destroyed the greenhouse. Therefore, the longer-term consequences of infection of 'Chardonnay' by the citrus strains could not be determined in this study. However, it is clear that an inadvertent introduction of CVC into the United

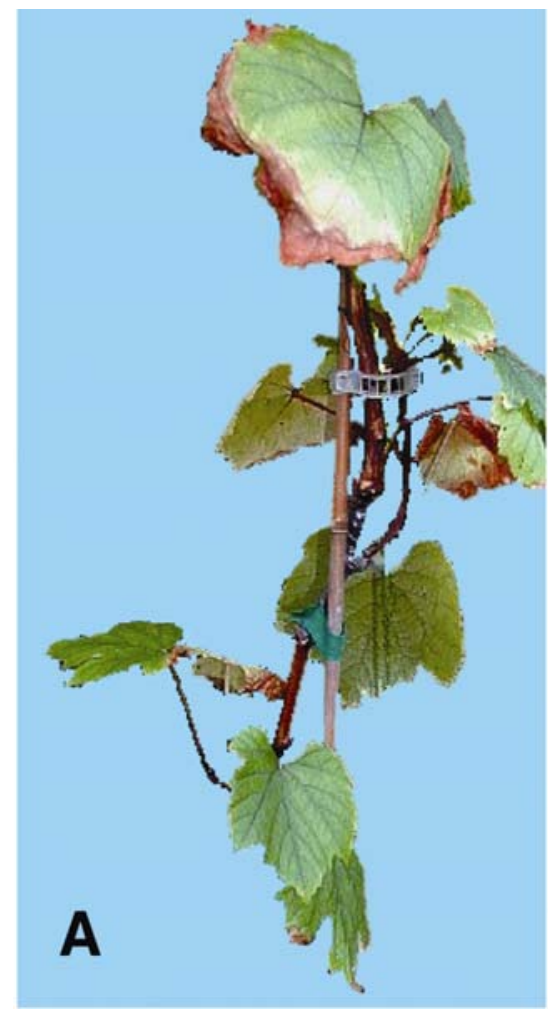

Fig. 2. Symptoms of Pierce's disease in 'Chardonnay' grapevine. A, Xylella fastidiosa citrus strain 9a5c (37). B, X. fastidiosa grape strain Temecula 042801.

Table 2. Pierce's disease severity in 'Chardonnay' grapevines inoculated with different strains of Xylella fastidiosa

\begin{tabular}{lccc}
\hline & \multicolumn{3}{c}{ Mean disease severity index after inoculation ${ }^{\mathbf{y}, \mathbf{z}}$} \\
\cline { 2 - 4 } Strains $^{\mathbf{x}}$ & $\mathbf{4 0}$ Days & $\mathbf{5 0}$ Days & $\mathbf{6 0}^{\mathrm{Days}}$ \\
\hline PD 042801 & $0.370 \mathrm{~B}$ & $0.696 \mathrm{~A}, \mathrm{a}$ & $0.798 \mathrm{~A}, \mathrm{a}$ \\
CVC9a5c & 0.340 & $0.380 \mathrm{~b}$ & $0.380 \mathrm{~b}$ \\
CVCL001 & 0.292 & $0.326 \mathrm{~b}$ & $0.372 \mathrm{~b}$ \\
\hline
\end{tabular}

x Pierce's disease strain Temecula 042801, and citrus strains CVC9a5c and CVCL001.

y See text for explanation of how the disease severity index was calculated. The range of values is 0 to 1 .

${ }^{\mathrm{z}}$ When the mean disease severity index values differed over time for a particular strain, differences are denoted by uppercase letters. When the mean disease severity differed among strains for a given date, differences are denoted by lowercase letters. Means followed by the same letter are not significantly different $(P=0.05)$

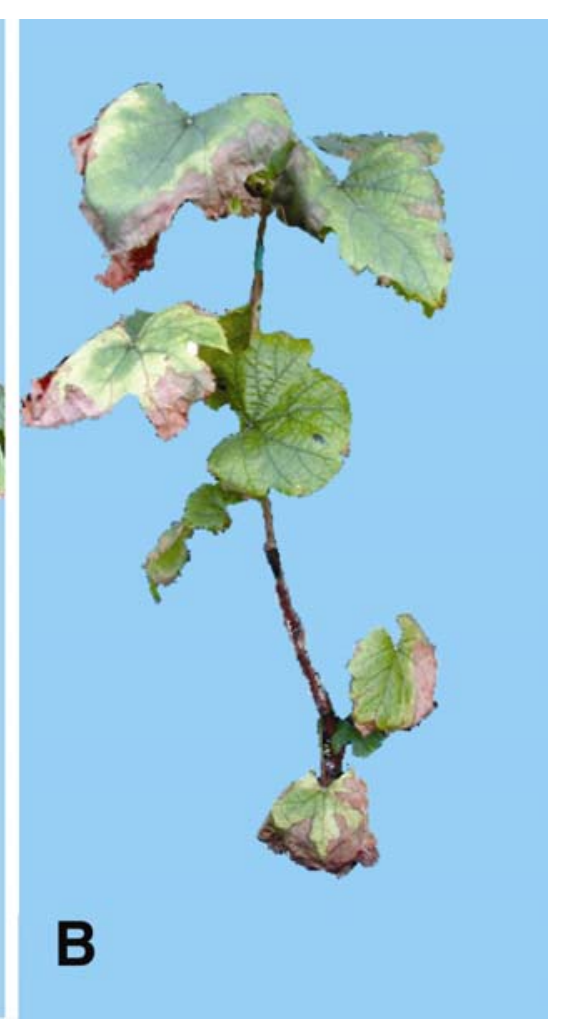

States would directly threaten the grape as

plasmid $(6,16)$ DNA, as well as sequence cultured $X$. fastidiosa $(7,16)$, have consistently shown the existence of distinct ships among citrus, coffee, and grapevine were estimated using rep-PCRDNA (RAPD)-PCR-based DNA markers. DA having a coefficient of similarity of only 0.4 (32). The citrus and coffee strains also induce symptoms in their hosts of origin ated with Pierce's disease of grapevine $(5,14,20,38)$. In spite of this distant genetic and pathologic relationship to PD strains,

(1)


our work establishes that citrus and coffee strains can incite PD symptoms in grapevine. It is interesting that PD was reported in Costa Rica in 1979 (12), and more recently $X$. fastidiosa has been reported to be causing both CVC (W. Villa Lobos, personal communication) and CLS (34) in Costa Rica. Are both PD and CVC/CLS strains of $X$. fastidiosa present in Costa Rica, or is the PD reported in Costa Rica caused by infection of grapevine by CVC/CLS strains? We note that although $X$. fastidiosa causes epidemic diseases of both citrus (14) and coffee (9) in Brazil, PD of grapevine has not been reported there. Some hosts of $X$. fastidiosa may show moderate symptoms when grown in the greenhouse, but none when grown in the field (A. H. Purcell, unpublished $o b$ servations). Thus, it may be possible that Brazilian grapevines are infected with CVC strains of $X$. fastidiosa without showing clear disease symptoms.

The basis of both host selection and disease induction by $X$. fastidiosa are not understood. However, full genome sequence data reveal that $X$. fastidiosa does not possess the HRP/avr gene system described in other bacterial pathogens of plants and animals (37). We note that although the citrus and coffee strains of $X$. fastidiosa produced PD symptoms after inoculation into 'Chardonnay' grapevine, disease severity was significantly less for these strains than what were observed for the "homologous", strain Temecula 042801 (Table 2). We have also shown that strains of $X$. fastidiosa isolated from diseased coffee and citrus in Brazil are able to induce symptoms of PD in a set of six commercial grape $(V$. vinifera) cultivars (Table 1) and identified a strain of $X$. fastidiosa, 2105 (citrus), that overall induced less severe symptoms than did the other strains tested from citrus and coffee. Strain 2105 also induced fewer symptomatic plants in each of six tested grape varieties than did the strains from citrus and coffee (Table 1). These observations could form the basis for experimental dissection of the mechanisms that underlie virulence in the citrus, as well as grapevine, strains of $X$. fastidiosa, using the recently available genomic sequence information (37) and systems for genetic analysis of this pathogen $(13,24,31)$ that are being developed.

\section{ACKNOWLEDGMENTS}

Funding for this research was provided in part by research grant $99 / 04345-3$ of the functional genome project of FAPESP (Fundacão de Amparo à Pesquisa do Estado de São Paulo).

\section{LITERATURE CITED}

1. Anonymous. 1994. California Plant Pest and Disease Report 13:(No. 1-2):8-10.

2. Anonymous. 2000. CVC: Sintomas estao mais graves. Rev. Fundecitrus 99:8-9.

3. Brlansky, R. H., Davis, C. L., Timmer, L. W., Howd, D. S., and Contreras, J. 1991. Xylemlimited bacteria in citrus from Argentina with symptoms of citrus variegated chlorosis. (Abstr.) Phytopathology 81:1210.
4. Brlansky, R. H., Timmer, L. W., French, W. J., and McCoy, R. E. 1983. Colonization of the sharpshooter vectors, Oncometopia nigricans and Homalodisca coagulata, by xylemlimited bacteria. Phytopathology 73:530-535.

5. Chang, C. J., Garnier, M., Zreik, L., Rossetti, V., and Bove, J. M. 1993. Culture and serological detection of the xylem-limited bacterium causing citrus variegated chlorosis and its identification as a strain of Xylella fastidiosa. Curr. Microbiol. 27:137-142.

6. Chen, J., Chang, C. J., and Jarrett, R. L. 1992. Plasmids from Xylella fastidiosa strains. Can. J. Microbiol. 38:993-995.

7. Chen, J., Jarret, R. L., Qin, X., Hartung, J. S., Chang, C. J., and Hopkins, D. L. 2000. 16SrDNA analysis of Xylella fastidiosa. Syst. Appl. Microbiol. 23:349-354.

8. Davis, M. J., French, W. J., and Schaad, N. W. 1981. Axenic culture of the bacteria associated with phony disease of peach and plum leaf scald. Curr. Microbiol. 5:311-316.

9. de Lima, J. E. O., Miranda, V. S., Hartung, J. S., Brlansky, R. H., Coutinho, A., Roberto, S. R., and Carlos, E. F. 1998. Coffee leaf scorch bacterium: Axenic culture, pathogenicity, and comparison with Xylella fastidiosa of citrus. Plant Dis. 82:94-97.

10. de Lima, J. E. O., Miranda, V. S., Roberto, S. R., Coutinho, A., Palma, R. R., and Pizzolitto, A. C. 1997. Diagnose da clorose variegada dos citros por microscópio ótica. Fitopatol. Bras. 22(3):370-374.

11. Freitag, J. H. 1951. Host range of the Pierce's disease virus of grapes as determined by insect transmission. Phytopathology 41:920-934.

12. Goheen, A. C., Raju, B. C., Lowe, S. K., and Nyland, G. 1979. Pierce's disease of grapevines in Central America. Plant Dis. Rep. 63:788-792.

13. Guilhabert, M. R., Hoffman, L. M., Mills, D. A., and Kirkpatrick, B. C. 2001. Transposon mutagenesis of Xylella fastidiosa by electroporation of Tn5 synaptic complexes. Mol. Plant-Microbe Interact. 14:701-706.

14. Hartung, J. S., Beretta, J., Brlansky, R. H., Spisso, J., and Lee, R. F. 1994. Citrus variegated chlorosis bacterium: Axenic culture, pathogenicity, and serological relationships with other strains of Xylella fastidiosa. Phytopathology 84:591-597.

15. He, C. X., Li, W. B., Ayres, A. J., Hartung, J. S., Miranda, V. S., and Teixeira, D. C. 2000. Distribution of Xylella fastidiosa in citrus rootstocks and transmission of citrus variegated chlorosis between sweet orange plants through natural root grafts. Plant Dis. 84:622-626.

16. Hendson, M., Purcell, A. H., Chen, D., Smart, C., Guilhabert, M., and Kirkpatrick, B. 2001. Genetic diversity of Pierce's disease and other pathotypes of Xylella fastidiosa. Appl. Environ. Microbiol. 67(2):895-903.

17. Hopkins, D. L. 1989. Xylella fastidiosa: Xylem-limited bacterial pathogen of plants. Annu. Rev. Phytopathol. 27:271-290.

18. Hopkins, D. L., and Adlerz, W. C. 1988. Natural hosts of Xylella fastidiosa in Florida. Plant Dis. 72:429-431.

19. Hopkins, D. L., Adlerz, W. C., and Bistline, F. W. 1978. Pierce's disease bacteria occur in citrus trees affected with blight (young tree decline). Plant Dis. Rep. 62:442-445.

20. Li, W.-B., Pria, W. D., Jr., Teixeira, D. C., Miranda, V. S., Ayres, A. J., Franco, C. F., Costa, M. G., He, C.-X., Costa, P. I., and Hartung, J. S. 2001. Coffee leaf scorch caused by a strain of Xylella fastidiosa from citrus. Plant Dis. 85:501-505.

21. Li, W. B., Zreik, L., Fernandes, N. G., Miranda, V. S., Teixeira, D. C., Ayres, A. J., Garnier, M., and Bové, J. M. 1999. A triply cloned strain of Xylella fastidiosa multiplies and induces symptoms of citrus variegated chlorosis in sweet orange. Curr. Microbiol. 39:106-108.

22. Minsavage, G. V., Thompson, C. M., Hopkins, D. L., Leite, R. M. V. B. C., and Stall, R. E. 1994. Development of a polymerase chain reaction protocol for detection of Xylella fastidiosa in plant tissue. Phytopathology 84:456-461.

23. Mircetich, S. M., Lowe, S. K., Moller, W. J., and Nyland, G. 1976. Etiology of almond leaf scorch disease and isolation of the causal agent. Phytopathology 66:17-24.

24. Monteiro, P. B., Renaudin, J., JagouiexEveillard, S., Ayres, A. J., Garnier, M., and Bové, J. M. 2001. Stable transformation of Xylella fastidiosa $\mathrm{CVC}$ strain with oriC plasmids. Appl. Environ. Microbiol. 67(5):2263-2269.

25. Perring, T. M., Farrar, C. A., and Blua, M. J. 2001. Proximity to citrus influences Pierce's disease in Temecula Valley vineyards. Calif. Agric. 55(4):13-18.

26. Phillips, P. A. 1999. Vineyards, almond orchards threatened. Am. Fruit Grower 119(10):18F-18H.

27. Pooler, M. R., and Hartung, J. S. 1995. Genetic relationships among strains of Xylella fastidiosa from RAPD-PCR data. Curr. Microbiol. 31:134-137.

28. Pooler, M. R., and Hartung, J. S. 1995. Specific PCR detection and identification of $X y$ lella fastidiosa strains causing citrus variegated chlorosis. Curr. Microbiol. 31:377-381.

29. Purcell, A. H., and Hopkins, D. L. 1996. Fastidious, xylem limited plant pathogens. Annu. Rev. Phytopathol. 34:131-151.

30. Purcell, A. H., and Saunders, S. R. 1999. Glassy-winged sharpshooters expected to increase plant disease. Calif. Agric. 53(2):26-27.

31. Qin, X., and Hartung, J. S. 2001. Construction of a shuttle vector and transformation of $X y$ lella fastidiosa with plasmid DNA. Curr. Microbiol. 43:158-162.

32. Qin, X., Miranda, V. S., Machado, M. A., Lemos, E. G. M., and Hartung, J. S. 2001. An evaluation of the genetic diversity of Xylella fastidiosa isolated from diseased citrus and coffee in Sao Paulo, Brazil. Phytopathology 91:599-605.

33. Raju, B. C., Goheen, A. C., and Frazier, N. W. 1983. Occurrence of Pierce's disease bacteria in plants and vectors in California. Phytopathology 73:1309-1313.

34. Rodriguez, C. M., Obando, J. J., Villalobos, W., Moreira, L., and Rivera, C. 2001. First report of Xylella fastidiosa infecting coffee in Costa Rica. Plant Dis. 85:1027.

35. Rossetti, V., Garnier, M., Bove, J. M., Beretta, M. J. G., Teixlira, A. R. R., Quaggio, J. A., and deNegri, J. D. 1990. Presence de bacteries dans le xyleme d'orangers atteints de chlorose variegee, unenovelle maladie des agrumes au Brasil. C. R. Acad. Sci. (Paris) 310:345-349

36. Sherald, J. L. 1993. Pathogenicity of Xylella fastidiosa in American Elm and failure of reciprocal transmission between strains from elm and sycamore. Plant Dis. 77:190-193.

37. Simpson, A. J. G., and 113 others. 2000. The genome sequence of the plant pathogen $X y$ lella fastidiosa. Nature 406:151-157.

38. Varela, L. G., Smith, R. J., and Phillips, P. A. 2001. Pierce's Disease. Agriculture and Natural Resources Publ. 21600. University of California, Davis.

39. Wells, J. M., Raju, B. C., Huang, H., Weilburg, W. G., Mandelco-Paul, L., and Brenner, D. J. 1987. Xylella fastidiosa gen. Nov., sp. Nov: gram-negative, xylem-limited, fastidious plant bacteria related to Xanthomonas spp. Int. J. Syst. Bacteriol. 37(2):136-143.

40. Wells, J. M., Raju, B. C., Thomson, J. M., and Lowe, S. K. 1981. Evidence of the common etiology of phony peach and plum leaf scald diseases. Phytopathology 71:1156-1161. 